\title{
АНОТАЦІЯ ЯК РІЗНОВИД КОМПРЕСІЇ НАУКОВОГО ТЕКСТУ
}

Городецька В. А. Анотація як різновид компресії наукового тексту.

Статтю присвячено актуальній проблемі методики навчання української мови студентів-іноземців. Уміння здійснювати компресію тексту є необхідною умовою комплексної роботи 3 навчальною та науковою літературою 3 обраного фаху. Анотування є одним із різновидів такої діяльності. Автор аналізує типи анотації та пропонує систему роботи, що сприятиме формуванню умінь та навичок написання анотацій до текстів різних типів.

Ключові слова: анотація, алгоритм написання анотацій, мікротекст, компресія тексту, стандартні мовні кліше анотації. 
Городецкая В. А. Аннотация как разновидность компрессии научного текста.

Статья посвящена актуальной проблеме методики обучения украинскому языку студентов-иностранцев. Умение осуществлять компрессию текста является необходимым условием комплексной работы с учебной и научной литературой по выбранной специальности. Аннотирование является одной из разновидностей такой деятельности. Автор анализирует типы аннотации и предлагает систему работы, которая будет способствовать формированию умений и навыков написания аннотации текстов разных типов.

Ключевые слова: аннотация, алгоритм написания аннотации, микротекст, компрессия текста, стандартные языковые клише аннотации.

Gorodetska V. A. Abstract as a form of scientific text compression.

This article investigates actual problems of methods in teaching Ukrainian among foreign students. Ability to perform text compression is essential in comprehensing educational and scientific literature devoted to chosen specialty. Annotation is a kind of such activities. The author analyzes annotation types and offers a system of ways that will help skill formation in writing annotations to texts of different types.

Key words: abstract, annotation writing algorithm, microtext, text compression, standard linguistic annotation units.

У сучасному світі спостерігається процес глобалізації, що передбачає серед інших завдань, поставлених перед людиною постіндустріальної епохи, ознайомлення з культурою, світоглядом, світосприйняттям інших народів, оволодіння їх мовою. Студенти-іноземці технічних факультетів українських вищих навчальних закладів, свідомо вивчаючи українську мову, особливу увагу приділяються опануванню науковим стилем мовлення задля вдосконалення професійних фундаментальних знань із обраної спеціальності. Важливим етапом навчання $є$ робота над компресією тексту.

Компресія тексту (від лат. compressio стиснення) - особливий вид переказу, який передбачає передання зі сприйнятого тексту основного (суттєвого), використовуючи мовні засоби. Досягається за рахунок вилучення надлишкових елементів висловлювання, що мають другорядну інформацію, а також завдяки використанню більш компактних конструкцій (за рахунок лексичних і граматичних трансформацій). Компресія тексту необхідна для створення рефератів, тез, анотацій, рецензій, грунтується на розкритті смислової структури тексту-першоджерела. Робота над компресією тексту сприяє більш глибокому його розумінню. Лише той текст по справжньому осмислений, головний зміст якого можна презентувати у стисненій формі. Читаючи текст, слід виділяти смислові частини (підтеми тексту) і визначати зв'язки між ними, оскільки компресія здійснюється через розчленування тексту і називання виокремлюваних блоків. Інакше кажучи, уміння працювати $з$ текстом великою мірою залежить від розуміння його структури. Проблемою компресії наукового тексту займалися С. Гончаренко, Л. Мацько, Н. Ничкало, В. Різун. 
Одним із різновидів тексту є анотація. Анотація (від лат. anotation примітка) - особливий вид усної чи письмової інформації, у якій наявний перелік основних позицій повідомлення чи коротка характеристика змісту книги, статті, рукопису, тобто максимально скорочений обсяг джерела інформації. В анотації коротко подано зміст документа, що уможливлює розуміння його теми, перераховано проблеми, які з'ясовано в першоджерелі. Залежно від мети розмежовують кілька видів анотацій. За змістом вони бувають довідкові та рекомендаційні. Текст анотації зазвичай стандартизований. Складниками анотації є: інформація про зміст, мета анотації, адресат. Анотація - це найбільш загальна й коротка характеристика книги або статті. У будь-якій анотації зміст першоджерела не викладається, а лише презентується (називається тема, мета, перераховуються проблеми). В анотації може бути відображено композицію джерела: вступ, основну частину, висновки (з характеристикою їх композиційних та змістових особливостей). Обсяг анотації залежить від обсягу представленого в ній джерела. Зазвичай анотація містить 30-50 слів (або 3-5 речень), у деяких випадках анотація може бути представлена складним реченням. За змістом та метою анотації бувають довідкові та рекомендаційні. Довідкові (інформативні) анотації - це коротка об'єктивна інформація про тематику книги або статті. У ній не розкривається зміст як у рефераті, а тільки перераховуються питання, що розкриті в джерелі. Окрім того, у такій анотації можуть бути сформульовані мета роботи, методи подачі інформації, структура роботи, зазначено наявність ілюстративного матеріалу, сформульовано головний висновок, зроблений автором. Рекомендаційні анотації зазвичай містять не тільки інформацію про джерело, а й подають рекомендації щодо його використання тією чи тією категорією читачів. При цьому враховуються рівень їх підготовки, вікові характеристики тощо. Інакше кажучи, рекомендаційна анотація акцентує увагу, якому колу читачів може бути адресовано інформацію в анотованому джерелі. За кількістю джерел анотації бувають монографічні та групові. Монографічна анотація подає характеристику лише одного друкованого джерела - однієї книги або статті. Групова анотація - це анотація, що містить характеристику двох і більше друкованих джерел, що зазвичай близькі за тематикою та проблематикою. У груповій анотації розкривається інформація про спільність тематики представлених джерел, а також розкривається специфіка кожної книги або статті із групи представлених. Групова анотація передбачає вказівку, на кого розраховано інформацію.

Студентам пропонується алгоритм написання анотації:

1. Прочитайте назву статті. Поміркуйте щодо її тематики.

2. Знайдіть прізвище автора, яке може бути надруковане на початку або в кінці статті. Запишіть прізвище автора, ініціали. Якщо авторів кілька, то запишіть усіх авторів.

3. Визначте місце та рік видання статті, книги. 
4. Прочитайте статтю, розподіляючи ії на смислові частини, підтеми.

5. Дайте назву кожній частині, тобто складіть план статті.

6. Подумайте про смислове співвідношення частин, про характер викладу кожної частини і про мовні засоби оформлення тексту анотації.

7. Напишіть анотацію, визначте та сформулюйте, хто може послуговуватися матеріалами статті.

8. Відредагуйте текст анотації.

Робота над науковим текстом передбачає певні підготовчі етапи. Студенти аналізують мовне оформлення тексту, його зміст, що, на нашу думку, сприяє кращому усвідомленню структури тексту, його призначення. Під час підготовчої роботи подаються завдання, пов’язані 3 компресію тексту, пропонується комплекс вправ для актуалізації знань із фонетики, лексикології, граматики української мови, що сприяє формуванню україномовної особистості, розвитку мовної, мовленнєвої, комунікативної та соціокультурної компетентностей. Про лінгвістичні основи навчання студентів-іноземців писали Є. П. Голобородько, В. К. Іваненко, В. Г. Костомаров, Р. П. Мільруд, О. Д. Митрофанова, Г. О. Михайловська, Ю. І. Пассов, М. І. Пентилюк, А. М. Щукін.

Пропонуємо фрагмент тексту для студентів:

\section{корисні копалини Украӥни}

В Украйні зазвичай добувають корисні копалини з невеликих глибин (до 1 тис. м). Отюе, вони тісно пов'язані з будовою саме верхніх шарів земної кори. Тому для різних тектонічних структур характерні певні групи корисних копалин.

Корисні копалини осадового походження поширені переважно в межах тектонічних западин $i$ плит платформних областей, а також передгірських крайових прогинів. Тобто вони характерні для структур, які в минулому були басейнами нагромадження осадового матеріалу, щзо зносився з прилеглих територій.

Магматичні та метаморфічні породи потрібно шукати в горах зі слідами вулканічних процесів, а також у кристалічних щзитах, де близько до поверхні залягають давні магматичні та метаморфізовані породи. Формуються їхні родовища, як правило, на стиках літосферних плит. Наприклад, на континентах у місиях розвитку рифтових зон утворюються родовища марганию, заліза та міді. У зоні зіткнення материкових літосферних плит виникають поклади міді, сірки, урану. До них належать, у більшості випадків, рудні корисні копалини, а також графіт, алмази тощо. Утворюються вони в результаті остигання магми в тріщинах земної кори, метаморфізації магматичних чи осадових порід під впливом високої температури й тиску.

У межах Украӥни давні магматичні й метаморфічні породи виходять на поверхню або залягають на невеликих глибинах Українського кристалічного щчита. Із метаморфізованими архейськими та протерозойськими породами иъього масиву пов'язані великі поклади залізних руд (Криворізьке, Кременчуцьке, Білозерське, Керченське родовища), нікелю (Побузьке родовище), титану (центральна частина Придніпровської височини), урану (південна частина Придніпровської височини). Метаморфічного походження $і$ значні поклади графіту (Завалівське родовище). 3 явищами вулканізму $і$ викидами гарячої води, тріщинами земних надр пов'язані свинцево-цинкові та ртутні руди Донбасу, свинцево-цинкові - Закарпаття.

В Украйні розвідано 90 видів корисних копалин, які зосереджено майже у 8 тис. родовиш.

При господарському аналізі корисних копалин прийнято класифікацію корисних копалин за походженням - паливні, рудні, нерудні.

() В. А. Городецька, 2013. 


\section{Робота над мовним оформленням тексту}

1. Випишіть із тексту іменники - власні назви, що належать до I та II відмін, розподіліть їх за групами (тверда, м'яка, мішана).

2. Випишіть із тексту термінологічну лексику. Послуговуючись словниками, розтлумачте іiі значення.

3. До поданих прикметників доберіть із тексту іменники. Запишіть отримані словосполучення.

Зразок: корисні-корисні копалини.

Вулканічний, гірський, дорогочінний, земний, комплексний, кристалічний, лікувальні, літосферний, магматичний, метаморфічний, мінеральний, напівдорогоцінний, платформний, ртутний, свинцевоичинковий, тектонічний.

4. Виділені дієслова замініть на віддієслівні іменники. Залежні іменники поставте в потрібному відмінку, визначіть його. Користуйтеся словами для довідок.

Зразок: видобувати бурштин - видобуток бурштину.

Розробляти родовища - ...; розвідувати руду - ..,; використовувати озокерит - ...; виявити поклади - ..; утворювати газ - ..; оцінювати запаси - ....

Слова для довідок: утворення, оцінка, розвідка, виявлення, використання, розробка.

5. Випишіть із тексту терміни, іменники II відміни чоловічого роду. Поставте їх у родовому відмінку однини. Поміркуйте, які закінчення вони матимуть: - $a$ (-я) чи -y (-ю)? Перевірте правильність своїх думок за допомогою орфографічного словника української мови.

Студентам пропонуються граматичні відомості. Наприклад:

В українській мові назви неістот мають відповідний поділ.

1. Назви чітко окреслених предметів і понять. Це охоплювані зором предмети (ключ, дуб), частини тіла (палечь, лоб), дні тижня та назви місячів (понеділок, жовтень), різні міри (метр, кілограм), наукові терміни (атом, суфікс). У родовому відмінку однини використовуються закінчення -а (-я).

2. Назви нечітко окреслених предметів і понять. Це предмети, які не мають певних меж (космос, ліс), назви великих споруд (завод, стадіон), територій (Крим, Казахстан), збірні назви (горох, пісок), назви речовин (граніт, мармур), явищ (грім, вітер), дій (біг, розгляд), станів (сон, гнів), абстрактних понять (прогрес, мир). У родовому відмінку однини використовуються закінчення -у (-ю).

Наприклад: кваричит - кваричиту, фосфорит - фосфориту, графіт графіту. У родовому відмінку однин використовуються закінчення -у (-ю), оскільки иі слова означають назви речовин.

6. Слова та словосполучення із дужок поставте в потрібному відмінку. Визначте відміну та відмінок цих слів. 
У межах (Україна) давні магматичні й метаморфічні породи виходять на поверхню або залягають на (невеликі глибини) Українського кристалічного (щит). Львівсько-Волинський басейн знаходиться на (захід) (Украйна), має (площа) близько 10 тис. км ${ }^{2}$. Торфові родовища знаходяться переважно на Поліській (низовина), у річкових (долина). На глибині 300-350 м існують умови для утворення сумішей (вуглеводневий газ). У Кіровоградській області знаходяться (родовище) нікелевих (руда) (Побузьке, Деренюське $i$ Липовеньківське), у Дніпропетровській - алюмінієвих - (глинозем) (Малишівське і Вовчанське родовища), на Закарпатті - поліметалевих (руда) (Берегівське, Беганське і Мужієвське родовища). Родовища нерудної (сировина) для металургійної промисловості є в різних (район) України: магнезит (вогнетрив) - y Запорізькій $і$ Дніпропетровській областях, вогнетривкі глини - у Донецькій області (Часовоярське родовище), кваричтти у Житомирській, флюсові вапняки - у Донецькій області і (Крим).

7. Випишіть із тексту іменники власні назви й укладіть парадигми їх відмінювання. Послуговуйтеся таблицею відмінювання географічних назв.

Зразок:

$\begin{array}{lllll}\text { Н. в. Суми } & \text { Канів } & \text { Одесса } & \text { Біла Церква } & \text { Івано-Франківськ } \\ \text { Р. в. Сум } & \text { Канева } & \text { Одеси } & \text { БілоїЦеркви } & \text { Івано-Франківська } \\ \text { Д. в. Сумам } & \text { Каневу } & \text { Одесі } & \text { Білій Церкві } & \text { Івано-Франківську } \\ \text { Зн.в. Суми } & \text { Канів } & \text { Одесу } & \text { БілуЦеркву } & \text { Івано-Франківськ } \\ \text { Ор. в. Сумами } & \text { Каневом } & \text { Одесою Білою Церквоюо } & \text { Івано-Франківськом } \\ \text { М. в. (у) Сумах } & \text { (у)Каневі } & \text { (в)Одесі }(\text { б) БілійЦеркві } & \text { (в) Івано-Франківську } \\ \text { Кл. в. Суми } & \text { Каневе } & \text { Одесо Біла Церкво } & \text { Івано-Франківську }\end{array}$

Запам'ятайте, що українській мові є незмінювані іменники. До них належать:

1) слова іншомовного походження: таксі, радіо, Конго, Марокко;

2) жіночі прізвища - українські та іншомовного походження, що закінчуються на приголосний (Пентилюк, Сергійчук), на -енко, -ко (Павленко, Яиенко), російські прізвища на -ово (Журново), на -аго (Живаго), -их (Черних);

3) складноскорочені слова $(\mathrm{OOH}$, зам. директора).

Робота над змістом тексту:

1. Прослухайте текст, потім прочитайте його вголос.

2. Дайте відповіді на запитання до тексту: Який основний вугільний басейн України? У яких областях України знаходяться найбільші нафтогазові родовища $і$ як вони називаються? Яку площу займає Криворізький залізорудний басейн? Де розміщено поклади марганцевих руд в Україні? Де в Украӥні зосереджено поклади золота та уранових руд? Які нерудні корисні копалини $\epsilon$ в Україні? Які запаси дорогочінного та напівдорогоиінного каменю спостерігаються на території України?

3. Поставте запитання до виділених слів та словосполучень: I3 метаморфізованими архейськими та протерозойськими породами пов'язані ○ В. А. Городецька, 2013. 
великі поклади залізних руд (Криворізьке, Кременчуцьке, Білозерське, Керчинське родовища), нікелю (Побузьке родовище), титану (центральна частина Придніпровської височини), урану (південна частина Придніпровської височини). Донецький басейн у межах Украӥни (Великий Донбас) займає плому понад 50 тис. км² (тут залягає коксівне, газове вугілля, антрацит). Карпатський нафтогазоносний регіон охоплює родовища Передкарпаття, Украӥнських Карпат і Закарпаття. Більшість нафтових i газових родовищ знаходяться у Львівській та Івано-Франківській областях i приурочені до Передкарпатського прогину. Багаті залізні руди зосереджені в Криворізькому залізорудному басейні, Кременчуцькому і Білозерському залізорудних районах, дещзо бідніші - у Керченському басейні. Нікопольський марганцевий басейн - один із найбільших у світі, уміст марганцю в окисних рудах у середньому 25-30\%, а загальні запаси руди-понад 2 млрд. тонн. У Кіровоградській області знаходяться родовища нікелевих руд (Побузьке, Деренюське і Липовеньківське), у Дніпропетровській-алюмінієвих - глинозему (Малишівське і Вовчанське родовища), на Закарпатті - поліметалевих руд (Берегівське, Беганське $\boldsymbol{i}$ Муюнівське родовища). Унікальні родовища титанових руд розробляються в Житомирській $\boldsymbol{i}$ Дніпропетровській областях. На Кіровоградщині залягають уранові руди. За розвіданими запасами ртутної руди (кіновар), поклади якої виявлено в Донецькій $\boldsymbol{i}$ Закарпатській областях, наша країна посідає друге місие у світі.

4. Послуговуючись географічною картою, розкажіть про родовища корисних копалин в Україні та розпитайте товаришів в академічній групі про багатство надр їхньої Батьківщини.

5. Використовуючи дані таблиці, розкажіть про фізичні властивості металів.

Фізичні властивості металів

\begin{tabular}{|c|c|c|c|c|c|c|}
\hline Назва & $\begin{array}{c}\text { Сим- } \\
\text { вол }\end{array}$ & $\begin{array}{c}\text { Щіль- } \\
\text { ність }\end{array}$ & $\begin{array}{c}\text { Температура } \\
\text { плавки }\end{array}$ & $\begin{array}{c}\text { Супротив } \\
\text { матеріалу }\end{array}$ & $\begin{array}{c}\text { Коофіціснт } \\
\text { теплопровідності }\end{array}$ & $\begin{array}{c}\text { Коофіціснт ліній- } \\
\text { ного розширення }\end{array}$ \\
\hline Алюміній & $\mathbf{A l}$ & 2,70 & 659,1 & 2,69 & 207 & 22,58 \\
\hline Вольфрам & $\mathbf{W}$ & 18,8 & 3370 & 5,5 & 130 & 4,3 \\
\hline Залізо & $\mathbf{F e}$ & 7,87 & 1535 & 9,71 & 75 & 11,9 \\
\hline Золото & $\mathbf{A u}$ & 19,3 & 1063 & 2,22 & 310 & 16,0 \\
\hline Мідь & $\mathbf{C u}$ & 8,93 & 1083 & 1,67 & 398 & 13,4 \\
\hline Нікель & $\mathbf{N i}$ & $8,6-8,9$ & 1455 & 6,84 & 92 & 21,4 \\
\hline Олово & $\mathbf{S n}$ & 7,29 & 231,9 & 12,8 & 65 & 28,3 \\
\hline Свинець & $\mathbf{P b}$ & 11,34 & 327,3 & 20,6 & 34,89 & 7,7 \\
\hline Титан & $\mathbf{T i}$ & 4,5 & 1668 & 55 & 15,5 & 30,0 \\
\hline Цинк & $\mathbf{Z n}$ & 6.92 & 419,5 & 5,92 & 111 & \\
\hline
\end{tabular}

6. Ознайомтесь з інформацією, поданою в таблиці. Послуговуючись підручниками з хімії, таблицею Д. Мендєлєєва, запишіть хімічні символи запропонованих корисних копалин. Зробіть висновки щодо промислової класифікації корисних копалин, використовуючи конструкції: розподілясться на (що?), поділясться на (щио?), належсить до (чого?), входить до (чого?), містить у собі (ццо?). 


\begin{tabular}{|c|c|}
\hline \multicolumn{2}{|r|}{ Промислова класифікація корисних копалин } \\
\hline Тип & Назва корисних копалин \\
\hline 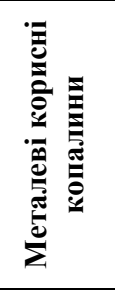 & $\begin{array}{l}\text { Чорні метали - залізо, марганець, хром, титан, кобальт. } \\
\text { Кольорові метали - мідь, свинець, ичнк, алюміній, олово, ртуть. } \\
\text { Благородні метали - золото, срібло, платина } \\
\text { Радіоактивні метали - уран, торій. } \\
\text { Рідкісні метали - иирконій, гафній, ніобій, тантал. } \\
\text { Легкі метали - берилій, літій, магній. } \\
\text { Розсіяні метали - індій, галій, германій. } \\
\text { Рідкоземельні метали - иерій, ітрій. }\end{array}$ \\
\hline 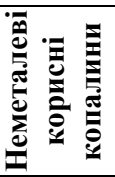 & $\begin{array}{l}\text { Пісок, гравій, глина, вапняк, мармур та ін. } \\
\text { Апатити, фосфорити, сірка, мінеральні солі, слюди, азбест, графіт та ін. } \\
\text { Дорогоцінне та напівдорогоцінне каміння - алмаз, рубін, аметист тощзо. } \\
\text { Горючі корисні копалини - вугілля, торф, нафта, горючі сланиі, горючі гази. }\end{array}$ \\
\hline
\end{tabular}

\section{Робота над компресісю тексту}

1. Ознайомтесь із зразками анотацій до підручників та посібників із Вашої спеціальності. Запишіть кілька прикладів анотацій до Ваших підручників. Зверніть увагу на мовне оформлення анотації.

\begin{tabular}{|c|c|}
\hline $\begin{array}{c}\text { Смислові } \\
\text { компоненти } \\
\text { тексту }\end{array}$ & Мовні засоби вираження смислу \\
\hline $\begin{array}{l}\text { Назва і тема } \\
\text { статті } \\
\text { (книги) }\end{array}$ & $\begin{array}{l}\text { Дана, представлена, подана стаття (книга)... } \\
\text { Стаття (книга) називається, має назву... } \\
\text { Тема статті (книги)...; представлену статтю (книга) присвячено темі...; } \\
\text { Статтю (книгу) написано на тему ...; у статті йдеться про... ; автор } \\
\text { статті (книги) розповідає про... }\end{array}$ \\
\hline $\begin{array}{l}\text { Проблема- } \\
\text { тика статті } \\
\text { (книги) }\end{array}$ & $\begin{array}{l}\text { У статті (книзі) розглянуто...; поставлено питання про те, що...; у } \\
\text { статті (книзі) автор торкається питань про...; автор висвітлює питання } \\
\text { про...; автор зупиняється на таких проблемах.... У статті (книзі) } \\
\text { викладено (що?)...; представлено наукову позицію...; узагальнено } \\
\text { досвід роботи...; подано аналіз (чого?)...; подано оцінку (чого?)...; } \\
\text { представлено опис (чого?); представлено наукове обгрунтування (чого?). }\end{array}$ \\
\hline $\begin{array}{l}\text { Композиція } \\
\text { статті } \\
\text { (книги) }\end{array}$ & $\begin{array}{l}\text { Стаття (книга) складається із...; починається з..; у статті (книзі) можна } \\
\text { виділити вступ, основну частину, висновки. Книга (стаття) складається } \\
\text { із ... глав, частин, розділів. У вступній (першій) частині йдеться про...; } \\
\text { підіймається питання про те, що...; викладається історія питання; } \\
\text { йдеться про... В основній частинрі статті (книги) подано опис...; подано } \\
\text { аналіз...;викладається наукова позиція ...; подано характеристику } \\
\text { (чого?)... В основній частині значне місце відведено (чому?)...; багато } \\
\text { уваги приділено (чому?)...; основну увагу звернено (на що?)... У } \\
\text { висновках зроблено підсумки дослідження; узагальнено сказане вище; } \\
\text { подано оцінку (чому?)...; підкреслено (що?)...; статтю завершено (чим?)... }\end{array}$ \\
\hline $\begin{array}{l}\text { Включення } \\
\text { ілюстратив- } \\
\text { ного } \\
\text { матеріалу до } \\
\text { статті (книги) }\end{array}$ & $\begin{array}{l}\text { У статті міститься велика кількість прикладів та ілюстративного } \\
\text { матеріалу. Автор наводить факти, цифри, відомості, що ілюструють та } \\
\text { підтверджують основні положення статті. Автор спирається на цифри, } \\
\text { факти, дані. У статті наведено цитати (звідки?). Автор цитує } \\
\text { висловлювання (кого?), слова (чиї?), цитує (кого?). }\end{array}$ \\
\hline
\end{tabular}




\begin{tabular}{|l|l|}
\hline \hline $\begin{array}{l}\text { Мета статті } \\
\text { (книги) }\end{array}$ & $\begin{array}{l}\text { Мета автора статті (книги) полягає в тому, щоб висвітлити, } \\
\text { узагальнити (що?); подати аналіз (чого?), оцінка (чого?). Стаття } \\
\text { (книга) має на меті показати, узагальнити... }\end{array}$ \\
\hline $\begin{array}{l}\text { Адресат } \\
\text { статті (книги) }\end{array}$ & $\begin{array}{l}\text { Статтю (книгу) адресовано спеціалістам / неспеціалістам; широкому } \\
\text { колу читачів; статтю (книгу) розраховано (на кого?); стаття (книга) } \\
\text { цікава для... }\end{array}$ \\
\hline
\end{tabular}

2. Ознайомтесь із стандартними кліше для написання анотації тексту. Напишіть кілька варіантів анотації до поданого тексту за фахом. Проаналізуйте їх мовні особливості.

3. Напишіть розгорнуті тези до тексту за фахом. На основі поданих тез складіть анотацію.

4. Використовуючи тезовий план, відновіть основний зміст тексту.

5. Прочитайте подані висловлювання. 3'ясуйте зміст прочитаного, сформулюйте тезу.

Криворізький залізорудний басейн - один із найбільших залізорудних басейнів світу. Залізні руди тут добувалися ще скіфами в $V-I V \mathrm{~cm}$. до н. е. Криворізький басейн приурочений до центтральної частини Украйнського щзита і займає площу близько $300 \mathrm{kм}^{2}$ (Дніпропетровська $і$ частково Кіровоградська області). Основне промислове значення мають магнетитові $i$ залізисті квариити, у результаті збагачення яких дістають конщентрат із вмістом заліза до 65\%. У Кривбасі відомо понад 300 родовищ багатих залізних руд, їх розвідані запаси становлять 18 млрд. тонн. Нині видобування залізних руд ведеться вже на глибині 1000 м. Найперспективнішим районом на багаті залізні руди є Саксаганське рудне поле.

За запасами нерудних (неметалевих) корисних копалин Україна посідає одне 3 провідних місиь у світі. Так, родовища самородної сірки й озокериту в Передкарпатті - найбільші у світі. Озокерит використовується в парфумерії, легкій промисловості, медицині, а сірка - у хімічній промисловості. Родовища кам'яної солі розробляються в Донбасі (Артемівське, Слов'янське) і в Закарпатті (Солотвинське). Багаті на солі водойми Азово-Чорноморського узбережжя, особливо затока Сиваш. Хлоридносульфатні родовища калійних солей знаходяться в Передкарпатті - Калуш-Голинське, Стебниківське. Родовища нерудної сировини для металургійної промисловості є в різних районах Украӥни: магнезит (вогнетрив) - у Запорізькій $і$ Дніпропетровській областях, вогнетривкі глини - у Донецькій області (Часовоярське родовище), кварцити y Житомирській, флюсові вапняки - у Донецькій області й Криму. Як технічна сировина використовуються азбест (Побужжя, Призов'я), тальк, пірофілітові сланці (Житомирська область), слюда, бентонітові глини (Черкаська область), барит (Закарпатська область), графіт (Кіровоградська область). Сировиною для керамічної й скляної промисловості є польові шпати, скляні піски. Україна багата запасами цементної сировини й різноманітних будівельних матеріалів. За запасами гранітів, лабрадоритів (Житомирська область) Украӥна в Свропі є поза конкуренцією.

6. Ознайомтесь із стандартними кліше для написання анотації до тексту за фахом. Побудуйте анотацію до запропонованого тексту на основі тез. Запишіть остаточний варіант анотації.

7. Підготуйте зразки анотацій (10) підручників, монографій економічного профілю. 
8. Знайдіть у тексті абзаци й проаналізуйте в кожному з них відому та нову інформацію. Запишіть це у вигляді розгорнутого тезового плану.

9. Підготуйте розповідь про запаси металів на Вашому континенті. Покажіть місце знаходження покладів на карті. На основі розповіді своїх товаришів підготуйте діалог-розпитування про родовища металів.

10. На основі тез самостійно складіть монологічне висловлювання 3 використанням тез та професійних термінів тексту за фахом з урахуванням інформації тексту та іiі розташування.

11. Побудуйте анотацію з використанням мовних кліше на основі тез тексту за фахом.

Робота над анотуванням тексту може базуватися на іншому різновиді компресії тексту - укладання тезового плану, що передбачає такі різновиди завдань:

1. Прочитайте дві мікротексти А і Б. Зіставте їх за змістом. Виділіть базові речення-тези.

A Фінанси держави - ие система грошових фондів, які має держава $і$ які спрямовуються на фінансове забезпечення ї̈ функиій: управління, оборону, сочіальні гарантії, охорону навколишнього середовища тощо. Державні фінанси включають у себе механізм мобілізаиї ресурсів та їхнє зосередження в розпорядженні держави, тому як барометр відображають загальний стан економіки. Водночас вони слугують потужним важелем впливу на економіку та темпи ї̈ розвитку. Держсвний бюджет - система грошових відносин, яка виникає між державою, з одного боку, $i$ підприсмствами, організаціями та населенням, з іншого, з метою формування та використання централізованого фонду грошових ресурсів для задоволення суспільних потреб. Іншими словами, це- щорічний баланс надходжень $i$ видатків, який розробляють державні органи для активного впливу на економічний процес та підвищення його ефективності.

Б Фінанси населення - це грошові фонди, які утворюються у жителів крайни з надходжень, отриманих від трудової, господарської та іншої діяльності $і$ які спрямовуються на примноження їх власності та підвищення добробуту. Вони виражають сукупність гротових відносин, що виникають навколо акумуляиії й використання заощаджень, страхових та пенсійних фондів для потреб нагромадження й розвитку соиіальної інфраструктури. Держава, застосовуючи такі мобілізаційні механізми, як податкова система, страхування, пенсійні відрахування, митні, рентні та інші платежі, формує ресурси для державних фінансів, за рахунок яких можливими стають відповідні перегрупування ресурсів, стимулювання структурних зрушень в економічі і формування нових галузей. Іншу частину коштів населення утворюють добровільні внески й пожертвування до грочових ресурсів громадських організацій $i$ політичних партій, спеціальних иільових фондів і коштів благодійних організащій, що використовуються для надання різноманітних сочіальних послуг. Основними принципами утворення цे використання фінансів населення $\epsilon$ добровільність, громадська спрямованість, здебільшого некомериійний характер руху, самоокупність $i$ самофінансування. Особливу форму організаиії фінансів на добровільних засадах становлять спеціальні цільові й добровільні фонди.

2. Складіть тезовий план до тексту. До кожної тези дібрати основні думки.

3. Перекажіть зміст кожної тези логічно, адекватно до теми. 
4. Створіть діалог на матеріалі тексту з використанням елементів анотування. Наприклад:

- Як називається поданий текст?

- Поданий текст називається «Фінансова система Украӥни».

- На яку тему написано статтю?

- Статтю написано на тему фінансової системи України.

- Які проблеми піднімаються у статті?

- У статті піднімаються проблеми сутності фінансів держави та фінансів населення.

- Якими особливостями відзначається композиція статті?

- У статті можна виділити три композиційні частини.

5. Спробуйте продовжити діалог, відповідаючи на такі запитання:

- Про щзо йдеться в периій частині статті?

- Чому відводиться значне місие у другій частині статті?

- Про шео йдеться у третій частині статті?

- Чим завериується виклад матеріалу у кіниі статті?

- Якою є мета автора повідомлення?

- На кого розрахований матеріал статті?

6. Відтворіть зміст діалогу у вигляді монологічного висловлювання, використовуючи елементи анотування.

7. Складіть усну анотацію тексту. Запишіть по кілька варіантів до кожного структурного елементу анотації, використовуючи методичні рекомендації до використання мовних засобів, що оформлюють анотацію. Запишіть остаточний варіант анотації.

Отже, робота над компресією тексту дозволяє, по-перше, актуалізувати знання студентів-іноземців із лексикології, граматики, стилістики, зняти труднощі лінгвістичного та змістового характеру у сприйнятті тексту, а подруге, - сприяє більш повному, глибокому та всебічному розумінню наукового тексту, його авторської інтерпретації, розвитку комунікативномовленнєвих умінь та навичок, здатності використовувати необхідні мовні засоби залежно від мети висловлювання.

\section{Література}

1. Вейзе А. А. Смысловая компрессия текста при обучении иностранному языку / А. А. Вейзе // Методика и лингвистика. - М. : Наука 1981. - С. 25-47.

2. Вейзе А. А. Чтение, реферирование и аннотирование иностранного текста / А. А. Вейзе. - М. : Высшая школа, 1985. - 121 с.

3. Леонов В. П. Алгоритмизация процессов реферирования и аннотирования научно-технической литературы : дис. ... д-ра пед. наук / В. П. Леонов. - Л. : Ленинград, гос. ин-т культуры им Н. К. Крупской. $-1987 .-462$ с.

4. Леонов В. П. Реферирование и аннотирование научно-технической литературы / В. П. Леонов. - Новосибирск : Наука, Сибирское отделение, 1986. - 172 с.

5. Мацько Л. І. Культура української фахової мови : [навч. посібник] / Л. І. Мацько, Л. В. Кравець. - К. : ВЦ «Академія», 2007. - 360 с.

6. Онуфрієнко Г. С. Науковий стиль української мови : [навч. посібник] / Г. С. Онуфрієнко. - К. : «Центр навчальної літератури», 2006. -312 с.

7. Семеног О. М. Культура наукової української мови : [навч. посібник] / О. М. Семеног. - К. : ВЦ «Академія», 2010. - С. 106-113.

8. Культура фахового мовлення : [навч. посібник] / за ред. Н. Д. Бабич. Чернівці : Книги - XXI, 2006. - $496 \mathrm{c.}$ 